\title{
PENGARUH MODEL PEMBELAJARAN BERBASIS MASALAH TERHADAP HASIL BELAJAR FISIKA SISWA PADA MATERI POKOK FLUIDA DINAMIS DI SMA N 11 MEDAN T.P 2014/2015
}

\author{
Rizki Khodijah dan Derlina \\ Jurusan Fisika FMIPA Universitas Negeri Medan \\ Jalan Willem Iskandar Pasar V Medan, Sumatera Utara \\ Rizki.khodijah09@gmail.com
}

\begin{abstract}
ABSTRAK
The Penelitian ini bertujuan untuk mengetahui pengaruh model pembelajaran berbasis masalah terhadap hasil belajar siswa pada materi pokok fluida dinamis di kelas XI semester II SMA Negeri 11Medan T.P. 2014/2015. Jenis penelitian ini adalah quasi eksperimen dengan pretest-posttest control group design, dengan sampel penelitian dua kelas, kelas eksperimen (XI-6) dan kelas kontrol (XI-5). Instrumen yang digunakan untuk mengetahui hasil belajar siswa adalah tes hasil belajar dalam bentuk essay sebanyak 10 soal yang telah divalidasi oleh validator. Data yang diperoleh antara lain hasil pretes dan postes. Selanjutnya data tersebut dianalisis dengan statistik yang terdiri dari uji normalitas, uji homogenitas dan uji hipotesis.Hasil penelitian menunjukkan bahwa ada pengaruh yang signifikan model pembelajaran berbasis masalah terhadap hasil belajar siswa pada materi pokok fluida dinamis di kelas XI SMA Negeri 11 Medan T.P. 2014/2015.
\end{abstract}

Kata Kunci : pembelajaran berbasis masalah, hasil belajar

\section{ABSTRACT}

This research is aimed to determine the effect of problem based learning model toward student's learning outcomes in the subject matter of dynamic fluid in the second half of class XI SMA Negeri 11 Medan T.P. 2014/2015. This research is quasi experiment with pretest-posttest control group design, with a sample of two classes, the experimental class (XI-6) and a control class (XI-5). The instrument used to determine student learning outcomes are essay test in the form of 10 item that has been validated by the validator. The data obtained are the result of pretest and posttest. Furthermore, the data is analyzed statistically consisting of normality test, homogeneity, and hypothesis testing. The results showed that there was a significant effect on the model of problem based learning toward learning outcomes of students in the subject matter of dynamic fluid for the class of XI SMA Negeri 11 Medan T.P. 2014/2015.

Keywords : problem based learning, learning outcomes

\section{INTRODUCTION}

Pada abad 21, sistem pendidikan nasional menghadapi tantangan yang sangat kompleks dalam menyiapkan kualitas sumber daya manusia (SDM) yang mampu bersaing di era globalisasi. Upaya yang tepat untuk menyiapkan sumber daya manusia dan seyogianya berfungsi sebagai alat untuk membangun SDM yang bermutu tinggi adalah pendidikan. Untuk Mencapai tujuan pendidikan nasional pemerintah telah menyelenggarakan perbaikan - perbaikan 
peningkatan mutu pendidikan pada berbagai jenis dan jenjang. Namun fakta di lapangan belum menunjukkan hasil yang memuaskan.Masalah utama dalam pembelajaran pada pendidikan formal dewasa ini adalah. Kebanyakan siswa hanya menghafal konsep dan kurang mampu menggunakan konsep tersebut jika menemui masalah dalam kehidupan nyata yang berhubungan dengan konsep yang dimiliki. Lebih jauh lagi, bahkan siswa kurang mampu menentukan masalah dan merumuskannya. Berbicara mengenai proses pembelajaran dan pengajaran yang sering membuat kita kecewa. Walau demikian, kita menyadari bahwa ada siswa yang mampu memiliki tingkat hafalan yang baik terhadap materi yang diterimanya, namun kenyataannya mereka sering kurang memahami dan dan mengerti secara mendalam pengetahuan yang bersifat hafalan tersebut. (Trianto.2011:4)

Dari hasil wawancara dengan guru fisika di SMA Negeri 11 Medan mengatakan bahwa salah satu kendala dalam melaksanakan pembelajaran yaitu tersedianya laboratorium tetapi alat dan bahan masih kuranglengkap.Beliau mengatakan bahwa ketuntasan belum optimal, nilai rata - rata ujian pertengahan semester hanya mencapai 67,34 , sedangkan ketuntasan kompetensi minimum (KKM) pada materi fisika adalah 70.Dari hasil angket yang disebarkan pada hari Selasa 16 Desember 2014 pada siswa kelas XISMA Negeri 11 Medan Tahun Pembelajaran 2014/2015 yang terdiri dari 35 orang siswa, diketahui kegiatan belajar mengajar fisika yang berlangsung dikelas hanya mencatat dan mengerjakan soal-soal, hal ini menyebabkan siswa kurang menyukai pelajaran fisika dan menganggap belajar fisika itu menjenuhkan dan membosankan, hal ini dapat dilihat dari pendapat siswa terhadap kegiatan proses pembelajara fisika yang berlangsung di kelas yaitu $60 \%$ berpendapat fisika adalah pelajaran yang sulit dipahami dan membosankan , 35\% (14 orang siswa) berpendapat fisika biasa-biasa saja, dan hanya 5\% (2 orang siswa) yang berpendapat fisika menarik dan menyenangkan. Selain itu $100 \%$ siswa mengatakan bahwa kegiatan proses pembelajaran yang berlangsung di kelas hanya mencatat dan mengerjakan soal.Dari hasil angket juga menunjukkkan bahwa siswa jarang untuk mengulang pelajaran dirumah meskipun mereka mempunyai buku dan kurang berkeinginan untuk mempelajari fisika di luar sekolah,hal ini menyebabkan rendahnya hasil belajar siswa.

Dari uraian masalah di atas, salah satu alternatif yang dapat digunakan untuk mengatasi kesulitan tersebut adalah dengan menciptakan suasana pembelajaran yang langsung berhubungan dengan kehidupan sehari-hari. Model pembelajaran berdasarkan masalahadalah salah satu upaya solusinya, model pembelajaran ini merupakan suatu model pembelajaran yang didasarkan pada banyaknya permasalahan yang membutuhkan penyelidikan autentik yakni penyelidikan yang membutuhkan penyelesaian nyata dari permasalahan yang nyata. Model pembelajaran ini membantu siswa mengembangkan kemampuan berfikir dan mengembangkan kemampuan dalam memecahkan masalah kehidupan seharihari, sehingga siswa lebih paham terhadap konsep fisika yang berkaitan dengan kehidupan sehari-hari.

Berdasarkan latar belakang masalah diatas, maka penulis terdorong untuk melakukan penelitian dengan judul Pengaruh Model Pembelajaran Berbasis Masalah Terhadap Hasil Belajar Siswa Kelas XI Semester Genap Pada Materi Pokok Fluida DinamisDi SMA Negeri 11 Medan T.P 2014/2015.

\section{METODE PENELITIAN}

Jenis penelitian ini adalah quasi exsperiment dengan desain penelitian pretest-posttest control group design. Penelitian dilaksanakan di SMA Negeri 11 Medan Medan yang beralamatkan di Jln. Pertiwi no 93. Waktu penelitian yaitu pada semester II tahun pelajaran 2013/2014, tepatnya di bulan April- Mei 2015 
Populasi dalam penelitian ini adalah semua siswa-siswi kelas XI SMA Negeri 11 Medan pada semester genap T.P. 2014/2015, yang terdiri dari 6 kelas. Dengan

menggunakan teknik cluster random sampling, diperoleh sampel dari populasi sebanyak 2 kelas. Kelas eksperimen adalah kelas X-6 yang diberi perlakuan menggunakan model pembelajaran berbasis masalah dan sebagai kelas kontrol adalah kelas X-5 yang dibelajarkan menggunakan pembelajaran konvensional.

Instrumen yang digunakan dalam penelitian ini adalah tes hasil belajar siswa dalam bentuk essay test yang berjumlah 10 soal. Tes hasil belajar divalidasi terlebih dahulu dengan validitas isi.

\section{HASIL DAN PEMBAHASAN \\ Hasil Penelitian}

Ringkasan data pretes di kelas eksperimen dan kelas kontrol dapat dilihat pada tabel 1 di bawah ini.

Tabel 1 Ringkasan Data Pretes Kelas Eksperimen dan Kelas Kontrol

\begin{tabular}{|c|c|c|c|c|c|c|}
\hline \multicolumn{4}{|c|}{ Kelas Eksperimen } & \multicolumn{3}{|c|}{ Kelas Kontrol } \\
\hline $\begin{array}{l}\text { Interv } \\
\text { al } \\
\text { Nilai }\end{array}$ & $\mathrm{F}$ & $\begin{array}{l}\text { Rata- } \\
\text { rata }\end{array}$ & $\begin{array}{l}\text { Standar } \\
\text { Deviasi }\end{array}$ & $\begin{array}{l}\text { Interval } \\
\text { Nilai }\end{array}$ & $\mathrm{F}$ & $\begin{array}{l}\mathrm{Ra} \\
\mathrm{a}- \\
\text { rat }\end{array}$ \\
\hline $5-12$ & 3 & \multirow{8}{*}{33,13} & \multirow{8}{*}{13,3} & $5-12$ & 3 & \multirow{8}{*}{$\begin{array}{l}28 \\
43\end{array}$} \\
\hline $13-21$ & 4 & & & $13-21$ & 6 & \\
\hline $22-30$ & 10 & & & $22-30$ & 13 & \\
\hline $31-39$ & 3 & & & $31-39$ & 5 & \\
\hline $40-48$ & 5 & & & $40-48$ & 3 & \\
\hline $49-57$ & 7 & & & $49-57$ & 2 & \\
\hline \multicolumn{2}{|c|}{$=1060$} & & & \multicolumn{2}{|l|}{$=910$} & \\
\hline \multicolumn{2}{|c|}{$\mathrm{n}=32$} & & & \multicolumn{2}{|l|}{$\mathrm{n}=32$} & \\
\hline
\end{tabular}

Untuk melihat secara rinci hasil pretes masing-masing kelas dapat dilihat grafik batang distribusi nilai pretes di kelas eksperimen dan di kelas kontrol pada gambar 1 di bawah ini.

Gambar 1 Grafik Batang Distribusi Nilai Pretes Kelas Eksperimen

\section{Uji Normalitas Data Pretes}

ingkasan uji normalitas data pretes dapat dilihat pada tabel 2 di bawah ini.

Tabel 2 Ringkasan Uji Normalitas Data Pretes

\begin{tabular}{|l|l|l|l|}
\hline \multirow{2}{*}{ Kelas } & \multicolumn{2}{|l|}{ Data Pretes } & \multirow{2}{*}{ Kesimpulan } \\
\cline { 2 - 3 } & $\mathrm{L}_{\text {hitung }}$ & $\mathrm{L}_{\text {tabel }}$ & \\
\hline Eksperimen & 0,1222 & 0,157 & Normal \\
\hline Kontrol & 0,1279 & 0,157 & Normal \\
\hline
\end{tabular}

\section{Uji Homogenitas Data Pretes}

Ringkasan data homogenitas pretes di kelas kontrol dan kelas eksperimen dapat dilihat pada tabel 3 di bawah ini.
Tabel 3 Ringkasan Data Homogenitas Pretes di Kelas Eksperimen dan kelas Kontrol

\begin{tabular}{|l|l|l|l|c|}
\hline Data & Varians & $\mathrm{F}_{\text {hitung }}$ & $\mathrm{F}_{\text {tabel }}$ & Kesimpulan \\
\hline $\begin{array}{l}\text { Pretes kelas } \\
\text { eskperimen }\end{array}$ & 177,02 & 1,68 & 1,83 & Homogen \\
\cline { 1 - 2 } $\begin{array}{l}\text { Pretes kelas } \\
\text { kontrol }\end{array}$ & 105,27 & 1,43 & 1,83 & Homogen \\
\cline { 1 - 2 } $\begin{array}{l}\text { Postes kelas } \\
\text { eskperimen }\end{array}$ & 104,2 & & & \\
\cline { 1 - 2 } $\begin{array}{l}\text { Postes kelas } \\
\text { kontrol }\end{array}$ & 148,3 & & & \\
\hline
\end{tabular}

\section{Uji Kesamaan Rata-rata Pretest (Uji t Dua Pihak)}

Ringkasan perhitungan uji kesamaan rata-rata pretes dapat dilihat pada tabel 4 di bawah ini.

Tabel 4 Ringkasan Perhitungan Uji Kesamaan Rata-rata pretes 


\begin{tabular}{|c|c|c|c|c|}
\hline Data & Rata-rata & $\mathrm{t}_{\text {hitung }}$ & $\mathrm{t}_{\text {tabel }}$ & $\begin{array}{l}\text { Kesinpada kelas eksprimen. Gambar } 4 \text { di bawah } \\
\text { lan ini menunjukkan perbandingan peningkatan }\end{array}$ \\
\hline $\begin{array}{l}\text { Pretes kelas } \\
\text { eksperimen }\end{array}$ & 33,13 & & & Kemanpsil belajar afektif di kelas eksperimen dan \\
\hline $\begin{array}{l}\text { Pretes kelas } \\
\text { kontrol }\end{array}$ & 28,43 & 1,582 & 1,999 & $\begin{array}{l}\text { k sam@erlarmbar } 4 \text { perbandingan hasil belajar di } \\
\text { kedua } \\
\text { kelompo } \\
\text { sama }\end{array}$ \\
\hline
\end{tabular}

\section{Hasil Belajar Afektif}

Diagram batang hasil belajar afektif di kelas eksperimen dapat dilihat pada gambar 2 di bawah ini.

Gambar 2 Diagram Batang Hasil Belajar Afektif di Kelas Eksperimen

Gambar 3 Diagram Batang Hasil Belajar Afektif di Kelas Kontrol

Berdasarkan diagram batang diatas juga menunjukkan setiap pertemuan sikap afektif di kelas eksprimen maupun kelas kontrol siswa mengalami peningkatan, tetapi peningkatan yang signifikan terlihat

\section{Hasil belajar Psikomotorik}

Untuk penilaian psikomotorik juga dinilai oleh peneliti dan observer selama kegiatan proses pembelajaran berlangsung yang telah dilengkapi lembar penilaian psikomotorik.Adapun aspek yang dinilai adalah 1)merangkai alat dan bahan, 2) merangkaian percobaan sesuai dengan LKS, 3) membuat data percobaan, dan 4)membuat kesimpulan, untuk lebih jelasnya hasil belajar psikomotorik dapat dilihat pada lampiran 25:182. Untuk melihat hasil perkembangan dari afektif dan pskmotorik dapat dilihat diagram batang pada gambar 4.5 di bawah ini

Gambar 5 Hasil belajar psikomotorik dikelas eksperimen

\section{Data Postes Kelas Eksperimen Dan Kelas Kontrol}

Ringkasan data hasil belajar postes di kelas eksperimen dan kelas kontrol dapat dilihat pada tabel 5 dan 6 di bawah ini.

Tabel 5 Ringkasan Data Postes Kelas Kontrol

\begin{tabular}{|c|c|c|c|}
\hline \multicolumn{4}{|c|}{ Kelas Kontrol } \\
\hline Interval Nilai & $\mathrm{F}$ & $\begin{array}{l}\text { Rata- } \\
\text { rata }\end{array}$ & $\begin{array}{l}\text { Standar } \\
\text { Deviasi }\end{array}$ \\
\hline $30-38$ & 3 & \multirow{8}{*}{55,31} & \multirow{8}{*}{12,17} \\
\hline $39-47$ & 7 & & \\
\hline $48-56$ & 6 & & \\
\hline $57-65$ & 10 & & \\
\hline 66-74 & 4 & & \\
\hline $75-83$ & 2 & & \\
\hline \multicolumn{2}{|l|}{$=1770$} & & \\
\hline$n=32$ & & & \\
\hline
\end{tabular}


Tabel 6 Ringkasan Data Postes Kelas Eksperimen

\begin{tabular}{|c|c|c|c|}
\hline \multicolumn{4}{|c|}{ Kelas Eksperimen } \\
\hline $\begin{array}{l}\text { Interval } \\
\text { Nilai }\end{array}$ & $\mathrm{F}$ & Rata-rata & $\begin{array}{l}\text { Standar } \\
\text { Deviasi }\end{array}$ \\
\hline $50-56$ & 2 & \multirow{8}{*}{73,28} & \multirow{8}{*}{10,2} \\
\hline $57-63$ & 2 & & \\
\hline $64-70$ & 11 & & \\
\hline $71-77$ & 7 & & \\
\hline $78-84$ & 4 & & \\
\hline $85-92$ & 6 & & \\
\hline \multicolumn{2}{|l|}{$=2345$} & & \\
\hline$n=32$ & & & \\
\hline
\end{tabular}

Grafik batang distribusi nilai postes di kelas eksperimen dan kelas kontrol dapat dilihat pada gambar 5 dan 6 di bawah ini.

Gambar 6 Grafik Batang DistribusiNilai Postes Kelas Eksperimen

Gambar 7 Grafik batang distribusi nilai postes di kelas kontrol

\section{Uji Normalitas Postes}

Data ringkasan postes di kelas kontrol dan kelas eksperimen dapat dilihat pada 7 di bawah ini.

Tabel 7 Ringkasan data normalitas postes

\begin{tabular}{|l|l|l|l|}
\hline \multicolumn{4}{|c|}{ Data Postes } \\
\hline Eksperimen & 0,1200 & 0,157 & Normal \\
\hline Kontrol & 0,1508 & 0,157 & Normal \\
\hline
\end{tabular}

\section{Uji Hipotesis(Uji t Satu Pihak)}

Uji $\mathrm{t}$ digunakan untuk mengetahui perbedaan hasil belajar siswa (postes) kelas eksperimen dan kelas kontrol setelah diberikan perlakuan pada kelas eksperimen.
Tabel 8 Ringkasan Perhitungan Uji t postes

\begin{tabular}{|l|l|l|l|l|}
\hline Data & $\begin{array}{l}\text { Rata- } \\
\text { rata }\end{array}$ & thitung & $\mathrm{t}_{\text {tabel }}$ & Kesimpulan \\
\hline $\begin{array}{l}\text { Postes kelas } \\
\text { eskperimen }\end{array}$ & 73,28 & & & $\begin{array}{l}\text { Ada pengaruh } \\
\text { yang signifikan } \\
\text { dari model } \\
\text { pembelajaran } \\
\text { inkuiri terhadap } \\
\text { hasir belajar } \\
\text { siswa }\end{array}$ \\
\hline $\begin{array}{l}\text { Postes kelas } \\
\text { kontrol }\end{array}$ & 55,31 & 1,695 & & \\
\hline
\end{tabular}

Pada tabel 8 diperoleh bahwa nilai postes $t_{\text {hitung }}>t_{\text {tabel }}$ yaitu 6,395 $>1,669$ maka $\mathrm{H}_{\mathrm{o}}$ ditolak dan terima $\mathrm{H}_{\mathrm{a}}$,dengan kata lain bahwa ada pengaruh yang signifikan dari model pembelajaran berbasis masalah terhadap hasil belajar siswa. Perhitungan hipotesis (uji t saatu pihak) dapat dilihat pada lampiran 13:163). Ringkasan perhitungan uji t postes dapat dilihat pada tabel 10 di bawah ini.

\section{Pembahasan}

Berdasarkan hasil penelitian hasil belajar menggunakan model pembelajaran berbasis masalah lebih tinggi daripada menggunakan model pembelajaran konvensional. Hal ini sejalan dengan penelitian Aqinoglu dan Tandogan (2006:78)bahwa kelas ekperimen yang menggunakan model pembelajaran berbasis masalah lebih berhasil daripada kelas kontrol yang menggunakan model konvensional.Ketika pretes dan postes nilai darikelas eksperimen dan kelompok kontrol mengalami peningkatan hasil belajar. Namun, kenaikan ini cukup tinggi terjadi pada kelas eksperimen.

Tingginya hasil belajar siswa di kelas eksperimen disebabkan karena model pembelajaran berbasis masalah merupakan model yang mengarahkan siswa untuk belajar mandiri atau belajar sendiri sehingga siswa lebih mudah untuk mengingat apa yang hasil dari pemecahan masalah yang diberikan guru.Aziz (2014 : 113) mengatakan bahwa pembelajaran berbasis masalah siswa lebih diarahkan untuk keterampilan belajar, sehingga membuat peserta didik untuk belajar sendiri atau belajar mandiri. 
Pada pembelajaran berbasis masalah juga peserta didik lebih banyak mengadakan diskusi dan melakukan presentasi dalam diskusi dan presentasi inilah peserta didik banyak melakukan tanya jawab baik kepada teman maupun kepada peneliti dengan melakukan tanya jawab tersebut peserta didik lebih paham terhadap materi yang deberikan dan mengurangi miskonsepsi siswa selama ini pada materi Fluida Dinamis. Wagiran (2007:13-14) penerapan model berbasis masalah menunjukkan arah perbaikan dalam menurunkan/mereduksi miskonsepsi secara memuaskan. Dalam melakukan diskusi dan presentasi peserta didik lebih leluasa mengeluarkan pendapatnya atau dengan kata lain peserta didik jauh lebih aktif. Selama proses pembelajaran dapat dilihat bahwa keaktifan mahasiswa mulai tampak pada putaran ke dua dan relatif konstan pada putaran berikutnya. Dengan demikian dapat dinyatakan bahwa penerapan pembelajaran berbasis masalah menunjukkan arah peningkatan keaktifan mahasiswa, namun demikian masih harus ditingkatkan mengingat keaktifannya belum mencapai titik yang tertinggi.

Hasil belajar afektif pada kelas yang menggunakan model pembelajaran berbasis masalah selalu mengalami peningkatan dari pertemua I, II, dan III, hal ini terjadi karena peserta didik semakin terbiasa menggunakan model pembelajaran berbasis masalah dari pertemuan I, II dan III. Penelitian sejalan dengan Abdullah dan Ridwan (2008 : 9) penggunaan model pembelajaran berbasis masalah pada aspek afektif setelah pelaksanaan ketiga siklus mengalami meningkatan nilai IPK dengankategori rata-rata "netral". Hal ini mengindikasikan bahwa tindakan yang dilakukan mampu merangsang siswauntuk melakukan percobaan eksperimen cukup baik.

Hasil belajar psikomotorik diperoleh dari eksperimen peserta didik dengan melakukan praktikum sesuai dengan LKS yang diberikan pada kelas ekperimen saja. Dari belajar psikomotorik selalu mengalami peningkatan dari pertemuan I, II dan III, hal ini disebabkan peneliti dan peserta didik semakin pandai mengoptimalkan waktu. Hal ini sejalan dengan penelitian Astika, Suma dan Suastra (2013 : 13) hasil belajar siswa pada aspek psikomotor terjadi peningkatan pada setiap siklusnya dengankategori"cukupterampil" pada siklus I meningkat menjadi kategori "terampil" pada siklus II dan siklus III.

$$
\text { Dalam melakukan ekperimen }
$$

peserta didik dilatih untuk merancang percobaan sesuai dengan langkah kerja yang ada pada LKS, Paramita, dkk (2014:11) pada pembelajaran berbasis masalah ketika pembelajaran di kelas siswa diajak untuk menguraikan ide tau konsep yang dicetuskan secara terperinci, serta terlatih merancang penyelidikan pada percobaan menggunakan langkah kerja yang dibuat secara berkelompok.

Walaupun penggunaan model pembelajaranberbasis masalah dapat meningkatkan hasil belajar dan aktivitas siswa, tetapi selama pembelajaran masih ada kendala yang dihadapi, yaitu peneliti tidak bisa mengoptimalkan waktu saat praktikum saat berjalan, kemudian masih ada siswa yang kurang tertarik dengan pembelajaran berbasis masalah karena telah terbiasa mengikuti pembelajaran konvensional atau yang sudah biasa diterapkan di kelas tersebut, seperti mencatat contoh soal dan mengerjakan soal-soalfisika. Hal ini sejalan dengan penelitian Husnidar, Ikhsan dan Rizal (2014 : 80) kendala - kendala dalam penerapan model pembelajaran berbasis masalah selama kegiatan pembelajaran berlangsung, diantaranya yaitu pada saat pembelajaran melalui tahapan pembelajaran berbasis masalah guru merasa kesulitan dalam mengorganisir waktu, dalam melaksanakan tahapan kegiatan praktikum masih dihadapi dengan kendala keterbatasan alat-alat praktikum, kemudian pada tahapan presentasi hasil praktikum, siswa masih kurang terbiasa tampil menyampaikan pendapatnyadi depan kelas. Siswa masih canggung dalam melaksanakan presentasi 
sehingga kurang tercipta suasana diskusi antar siswa.

Salah satu faktor yang paling menonjol pada penelitian ini yang menyebabkan hasil belajar siswa lebih tinggi di kelas yang menerapkan model pembelajaran berbasis masalah daripada di kelas yang menerapkan model konvensional adalah karena siswa lebih banyak belajar secara mandiri, hal ini mendorong siswa untuk terus menggali kemampuannya tentang materi yang disampaikan. Arends (2012:103) pembelajaran berbasis masalah berusaha membantu siswa menjadi pembelajar yang mengatur dirinya sendiri dan terus-menerus mendorong agar siswa mengeluarkan kemampuannya untuk mencari solusi solusi sendiri bagi masalah yang diberikan guru.

\section{KESIMPULAN DAN SARAN}

Berdasarkan hasil analisis dan uji statistik serta pembahasan maka disimpulkan bahwa Pembelajaran secara Konvensional sebelum diberikan perlakuan rata-rata pretes sebesar 28,43 dan setelah diberikan perlakuan rata-rata postes siswa sebesar 55,31. Pembelajaran dengan model Berbasis Masalahsebelum diberikan perlakuan rata-rata pretes sebesar 33,13 dan setelah diberikan perlakuan rata-rata postes siswa sebesar 73,28. Hasil Belajar afektif lebih tinggi di kelas ekperimen daripada di kelas kontrol. Hasil Belajar Psikomotorik mengalami peningkatan setiap pertemuan. Dari hasil uji hipotesis $t_{\text {hitung }}>t_{\text {tabel }}$ yaitu $6,395>1,669$, sehingga hasil belajar siswa dengan menerapkan model pembelajaran berbasis masalah memiliki efek yang lebih baik dibandingkan dengan pembelajaran konvensional.

\section{Saran}

Berdasarkan hasil penelitian dan kesimpulan di atas, maka sebagai tindak lanjut dari penelitian ini maka peneliti memiliki beberapa saran. Kepada guru ataupun calon guru yang ingin menggunakan model pembelajaran Berbasis Masalah supaya lebih banyak lagi mempersiapkan masalah-masalah dalam kehidupan sehari-hari yang menarik dan terkait pada materi pelajaran sehingga siswa akan lebih tertarik mengikuti pelajaran. Hendaknya melakukan simulasi sebelum mencobakan model ini terhadap siswa agar siswa lebih memahami dan terlatih dengan cara kerja model pembelajaran ini ketika melakukan penelitian,sehingga model pembelajaran berbasis masalah ini bisa diselesaikan tepat waktu.

\section{DAFTAR PUSTAKA}

Abdullah, A. G. Ridwan,T., (2008), Implementasi Problem Based Learning (PBL) Pada ProsesPembelajaran Di BPTP Bandung, Jurnal Pendidikan, program studi Pendidikan Teknik Elektro, FPTK UPI

Akinoglu, O. Tandingan, R.O., (2006), The Effects of Problem-Based Active Learning in ScienceEducation on Students' AcademicAchievement, Attitude and ConceptLearning, Jurnal pendidikan, Marmara University, Istanbul, Turkey

Astika, U., Suma, I., Suastra, I., (2013), Pengaruh Model Pembelajaran Berbasis Masalah Terhadap Sikap Ilmiah Dan Keterampilan Berfikir Kritis, Volume 3, e-Jurnal Pasca Sarjana Pendidikan Ganesha, Universitas Ganesha

Arends, R.I., (2013), Learning To Teach, Pustaka Pelajar, Yogyakarta

Aziz, M.S., (2014), The Effects of ProblemBased Learning on Self-Directed Learning Skills among Physics Undergraduates, Jurnal, Vol 3 No 1,International Journal of Academic Research in Progressive Education and Development, University of Baghdad

Paramitha,L.A.Sumarjo.Parno,

(2012),Pengaruh

Model

Pembelajaran Berbasis Masalah

(PBM) Terhadap Keterampilan Berpikir Kreatif Dan Metakognisi Pada Pembelajaran Fisika Siswa 
Kelas $\quad X \quad$ SMA Negeri 2 Wagiran, (2007), Meningkatkan Keaktifan

Lumajang,Jurnal Fisika,

FMIPA,Universitas Malang

Trianto, (2009), Mendesain Model Pembelajaran Inovatif Progresif, Kencana Prenada, Bandung
Mahasiswa Dan Reduksi

Miskonsepsi Melalui Pendekatan

Problem

Based

Learning,Jurnal,Dikti No39, Jurnal Kependidikan,Fakultas Teknik, Universitas Negeri Yogyakarta 